\title{
Coaches' Perceptions of the Reduction of Athletic Commitment for Division II Student-Athletes: Development and Validation of a Measure of Athletic/Academic Balance
}

\author{
Matt R. Huml \\ Texas Tech University \\ Marion E. Hambrick \\ University of Louisville \\ Mary A. Hums \\ University of Louisville
}

\begin{abstract}
Growing concerns exist regarding the amount of time student-athletes spend honing their athletic craft at the potential expense of their academic pursuits. Recently, the National Collegiate Athletic Association (NCAA) Division II Management Council approved the Life in the Balance (LITB) initiative to allow student-athletes more time for academics and other extracurricular activities beyond their sport(s). The purpose of this study was to develop a reliable and valid measurement scale assessing coaches' perceptions of balancing athletics and academics for studentathletes. Results of this study indicated three factors comprise the Athletic Academic Balance Scale (AABS): (a) policy impact, (b) contest reductions, and (c) midyear break. The AABS represents a reliable and valid scale to measure policy effectiveness for balancing athletics and academics for student-athletes. The scale extends role theory into student-athlete literature and helps assess the perception of internal stakeholders regarding future NCAA policies.
\end{abstract}

Keywords: athletic/academic balance, student-athlete, NCAA policy, life in the balance, Division II

Similar to millions of other incoming college students, student-athletes face the challenges of acclimating to the heightened expectations of a new academic

Huml is with the Dept. of Kinesiology \& Sport Management, Texas Tech University, Lubbock, Texas. Hambrick and Hums are with the Dept. of Health \& Sport Sciences, University of Louisville, Louisville, Kentucky. Address author correspondence to Matt Huml at matt.huml@ttu.edu. 
environment. Unlike other college students, however, student-athletes participate in varsity athletics, one of the most time-consuming activities available to students (Cantor \& Prentice, 1996; Paule \& Gilson, 2010). Intercollegiate athletics profoundly affects the higher education experience of student-athletes, who face challenges in meeting the heightened academic rigor expected in college courses while also adapting to increased expectations on the playing field (Lally \& Kerr, 2005; Miller \& Kerr, 2002). This juggling act has led to some student-athletes losing a degree of autonomy within academic activities, such as choosing a major and registering for certain courses (Hardin \& Pate, 2013; Huml, Hancock, \& Bergman, 2014). Student-athletes have a desire to increase their time available away from their sport, wishing they could experience the "regular college life without the athletics part" (Paule \& Gilson, 2010, p. 341).

In an effort to align the student-athlete experience with Division II's strategic positioning platform of integrating the athletic experience of student-athletes into higher education, the National Collegiate Athletic Association (NCAA) Division II President's Council initiated a review of the time spent by student-athletes in team-related activities (NCAA, 2010a). The Council's goal from this review was to create a policy aimed at easing the burden of athletic responsibilities for studentathletes, with the hope it would allow them to spend more time on academics. At the 2009 NCAA Convention, many university presidents at Division II institutions echoed similar concerns about student-athletes spending an inordinate amount of time on athletics (NCAA, 2010a). When NCAA researchers presented their findings from the review authorized by the President's Council, the results indicated Division II student-athletes had similar, and at times greater, athletic time commitments compared with Division I student-athletes (NCAA, 2010a). The steady augmentation of game schedules for each sport represented another concern, as it further expanded the time commitments of student-athletes and financial costs for athletic departments.

Following a discussion of these findings, NCAA Division II level administrators implemented the "Life in the Balance" (LITB) initiative at the 2010 NCAA Convention (NCAA, 2010a). A second phase of the initiative (NCAA, 2010b) incorporated changes including a later reporting date for student-athletes in fall sports, a seven-day "dead" period during the winter holiday break where no sport would have any team-related activities, and a reduced number of contests in all sports except football. The LITB package stressed the importance of implementing these changes in the following way:

Instead of perceiving the initiative taking away from these individuals [studentathletes], however, presidents and chancellors see these concepts as giving back in the form of student-athlete well-being, work/life balance, and more time to devote to the social and educational experience (NCAA, 2010a, p. 2).

While certain athletic department employees have championed the NCAA LITB package, coaches proved more pessimistic about the LITB package than other personnel (Hendrickson, 2013). The NCAA reported the coaches' general satisfaction with the policy scores were 16 percentage points lower than athletic department administrative personnel, faculty athletic representatives, and university presidents (Hendrickson, 2013). This may have occurred because coaches were not given the opportunity to voice their opinions during the initial implementation of the LITB package. In response to low satisfaction rates from coaches, one 
Division II conference commissioner mentioned how "we haven't connected with the coaches as well as we have with the other groups" (Hendrickson, 2013, p. 1). The initial LITB initiative package contained no mention of discussions with any coaches' associations, although it was discussed with student-athletes and athletic directors (NCAA, 2010a).

Despite the potential ramifications of this initiative, no previous studies have examined the effect of changing NCAA policies on the balance of athletics and academics for student-athletes. Furthermore, no established quantitative instrument exists to assess the athletic/academic balance of student-athletes from the perspective of collegiate coaches. The perception of college coaches is important because they spend the most time with varsity student-athletes in comparison with other university personnel (Kamusoko \& Pemberton, 2011). The LITB initiative directly impacts both student-athletes and coaches. Because of this strong relationship with each other and the policy, the purpose of this study was to develop a reliable and valid measurement scale assessing coaches' perceptions of balancing athletics and academics for student-athletes.

\section{Literature Review}

\section{Coach and Student-Athlete Interaction}

Coaches spend a substantial amount of time with their student-athletes, often becoming their most frequent university contact (Bruening \& Dixon, 2007; Giacobbi, Roper, Whitney, \& Butryn, 2002). This coach/athlete relationship can involve discussions related to athletic and academic issues, and even personal matters (Giacobbi et al., 2002; Weight, Cooper, \& Popp, 2015). Coaches often embrace this personal relationship, to the point of being available to their players at all times of the day for questions, comments, or simply lending an ear (Bruening \& Dixon, 2007). Providing this level of availability to student-athletes can be taxing to the coach and athlete, as it pulls the coach's free time away from family. In addition, a coach may actually be acting as a crutch for student-athletes to constantly reach out to for any higher education issues, creating a vicious cycle (Benford, 2007; Bruening \& Dixon, 2007; Dixon \& Bruening, 2007; Wolverton, 2014). The relationship between coach and student-athlete can also be heightened at schools with small athletic department budgets, such as Division II institutions (Nite, 2012). Many Division II institutions had one or fewer full-time employees dedicated to student-athlete academic services. This limited support requires Division II coaches to become more involved with their student-athletes' academic experiences, a skill they potentially lack (Nite, 2012).

Coaches who become vocal leaders supporting the importance of academics can have a profound and positive effect on their student-athletes (Bell, 2009; Navarro, 2015; Weight et al., 2015). Bell (2009) quoted an athlete stating, "It's really good when you have a coach that actually cares about your degree. All the coaches here know that you're here to get your education first. If we have a test during practice, we're gonna [sic] go to that test" (p. 26). One study found almost all student-athletes believed coaches had their best interests at heart regarding their academic success (Kamusoko \& Pemberton, 2011). Student-athletes were also supportive of increasingly rigorous NCAA policies pushing the importance 
of academics, saying, "I think it is good because it forces the student-athletes to be serious about their schoolwork and makes them realize that they are a student first" (Kulics, Kornspan, \& Kretovics, 2015, p. 8).

Unfortunately, coaches are predominantly assessed based on win-loss record (Weight et al., 2015). This pressure to win is not lessened at the Division II level (Nite, 2012). Schools also rarely incentivize their coaches monetarily to prioritize academics, as few coaches' contracts contain clauses related to team academic performance (Wilson \& Burke, 2013). When coaches face heightened sensitivity and scrutiny based on their team's athletic success, they may become more willing to push their student-athletes to pursue athletics over academics (Bimper, 2015; Navarro, 2015; Nite, 2012). Coaches and other athletic administrators often hold great power over their student-athletes' class schedules and chosen majors in an attempt to make sure coursework does not interfere with regularly scheduled athletic activities (Bell, 2009; Huml, Hancock, et al., 2014; Kulics et al., 2015). Relative to career development, student-athletes believe their coaches focus on athletes' career opportunities in sport rather than vocations related to their degree (Cummins \& O'Boyle, 2015). Coaches have been shown to emphasize keeping their student-athletes eligible for participation instead of aligning course and major selections with their long-term career goals and internship opportunities (Bell, 2009; Bimper, 2015). These misguided choices for courses and majors can have negative consequences on student-athletes' long-term job satisfaction and earning potential (Lawrence, Harrison, \& Stone, 2009).

\section{Theoretical Framework}

The situation arising from these conflicting responsibilities presents a connection to role theory. Role theory posits that focusing one's time and energy on a specific task reduces the time and energy available to complete other tasks (Barnett \& Gareis, 2006; Greenhaus et al., 2003). Role theory has also been characterized as human beings acting in a predictable and socially expected pattern (Biddle, 1986). While application of role theory has previously focused on participants speaking to their own available time and energy, other studies examined those close to the participants and how they perceive that time and energy is spent. For example, researchers have shown coaches are familiar with how their student-athletes use their time in college (Comeaux, 2015; Giacobbi et al., 2002; Weight et al., 2015). Dixon and Bruening (2007) previously reported how coaches make themselves available to their student-athletes at all hours, often resulting in them rescheduling family or job-related tasks to better support their players. The familiarity coaches have with their student-athletes provides them with an understanding of the dedication to their sport (i.e., athletic identity) and their rapport with teammates. These meetings also often go beyond athletics, with coaches counseling student-athletes on class and family-related difficulties as well (Giacobbi et al., 2002). This relationship between student-athlete and coach is so close coaches often create a feeling of the team being a "second family" (Dixon \& Bruening, 2007, p. 477). Coaches also understand the difficulties of student-athletes attempting to find a balance between academics and athletics, as coaches often prioritize academics when they start a new job (Gilson, Paule-Koba, \& Heller, 2013). This priority toward academics has also been shown to fade over time (Gilson et al., 2013). The significant pressure on college coaches to produce teams that are successful on the playing field 
can also be translated to student-athletes who spend more time on their sport than on their classes (Johnson, Pierce, Tracy, \& Ridley, 2015). This pressure to dedicate increased time to athletics has led to concerns about coaches not promoting academics enough to their student-athletes (Comeaux, 2015). This perception does not typify all coaches, as other studies have shown student-athlete satisfaction with coaches who highlight the importance of academics or even prioritize coursework over athletic obligations (Bell, 2009; Weight et al., 2015). Coaches have a special bond with their student-athletes. Coaches also are aware of the delicate balance between academics and athletics, and their own conflict with potentially pushing student-athletes toward greater sport participation at the cost of academics. Given the NCAA's increasing focus on how student-athletes spend their time, coaches are in the unique position to be directly impacted by any legislation regulating this topic. Their perceptions of how NCAA policy impacts the student-athlete's balance between academics and athletics can provide insight into how any new policy developments would influence the student-athlete academic and athletic balance.

Role theory has previously been applied to intercollegiate athletics, primarily on departmental employees, such as female head coaches and athletic trainers (Bruening \& Dixon, 2007, 2008; Dixon \& Bruening, 2005, 2007; Mazerolle \& Eason, 2013). These examinations of conflict between vocational and personal responsibilities for intercollegiate sport managers have further illuminated the difficulties of achieving balance within NCAA mandated standards of student-athlete athletic participation. Bruening and Dixon (2007, 2008; Dixon \& Bruening, 2005, 2007) further extended role theory into intercollegiate athletics by utilizing a multilevel approach (sociocultural, structural, and individual factors). For example, when coaches assess a decision affecting their personal and professional lives, they potentially consider individual (e.g., personality, values, gender), structural (e.g., job pressure, organizational culture, work schedule), and sociocultural (e.g., cultural norms, gender ideology) factors before making a decision (Dixon \& Bruening, 2005). While it is not the intention of this study to expand the findings within each of these levels, future studies on student-athletes involving role theory could apply sociocultural, structural, and individual factors.

This study represents the first attempt to examine the effect of NCAA policies related to student-athletes balancing academics and athletics by developing a reliable and valid measurement scale assessing coaches' perceptions for balancing athletics and academics for student-athletes. In addition, through the coaches' perspective, this study is the first application of role theory to examine the role conflict studentathletes experience when balancing academics and athletics (Bruening \& Dixon, 2007, 2008; Dixon \& Bruening, 2005, 2007). Lastly, this study is the first to apply role theory analyzing one stakeholder's perceptions of the activities of another stakeholder. Specifically, this study focuses on the perceptions of coaches as they relate to the activities of student-athletes. Future studies should collect data from the student-athletes themselves and other stakeholders.

\section{Method}

\section{Scale Development}

The current study sought to develop the Athletic Academic Balance Scale (AABS), designed to assess coaches' perceptions of the balance between academic and 
athletic activities for student-athletes as regulated by a governing body (i.e., NCAA). These regulations could include reduction of time spent through reduced game schedules, reduced practice time, required breaks from team-related activities, and subsequent benefits reaped by the institution or student-athlete from such a policy. It is the authors' intention for the instrument to be able to be administered to student-athletes, coaches, athletic administrators, and other stakeholders in the future. To create this instrument, the researchers completed the study in two steps. The first step used an exploratory factor analysis (EFA) to better comprehend the underlying structure of the AABS. The second step used a two-level confirmatory factor analysis (CFA) to verify the factor structure and further reinforce the reliability and validity for the scale.

In the process of developing the instrument, the authors initially reviewed the original LITB initiative and its subsequent revisions. This review revealed the intentions of the policy's introduction and its effect on each sport. Following the review, the authors met with two NCAA Division II athletic directors to further discuss the policy. This meeting allowed the athletic directors to communicate their perspectives on how the implementation of LITB has altered the athletic/academic balance of student-athletes, in addition to discussing the policy's impact on their athletic department personnel. Feedback from the athletic directors included whom to target with the study (head coaches) and slight language alteration to align the items with the application of the LITB initiative. The athletic administrators believed head coaches were an appropriate target population because of (a) their direct involvement with student-athletes and (b) their perceived lack of involvement in the policy's creation.

Once the authors reviewed the LITB policy, a review of the theoretical framework and supporting literature was initiated. Previous studies implementing role theory within the field of sport (Bruening \& Dixon, 2007, 2008; Dixon \& Bruening, 2005, 2007; Mazerolle \& Eason, 2013) were examined for theoretical application. Additional topics included student-athlete academic issues (Brewer, Van Raalte, \& Linder, 1993; Huml, Hancock, et al., 2014) and others highlighting the relationship between student-athlete athletic responsibilities and academic success (Lally \& Kerr, 2005; Miller \& Kerr, 2002). Following these steps, the authors constructed a 28 -item instrument with the following dimensions: (a) policy impact, (b) contest reductions, (c) midyear break, and (d) financial savings. Each of the dimensions is apparent in the LITB initiative, as it seeks a reduction of contests in almost every sport (contest reductions), a seven-day break from all sport activities (midyear break), and potential financial savings from less travel (financial savings).

In addition to aligning the items with the LITB initiative, items were also aligned with the approach used in Bruening and Dixon's (2007, 2008; Dixon \& Bruening, 2005, 2007) research on female college coaches in relation to role theory. Individual factors (e.g., personality, values, family structure, gender) are discussed within the policy impact (student-athletes can seek more employment opportunities due to more available time), contest reductions (fewer contests allow for more time to focus on academic obligations), and winter break dimensions (winter break allows student-athletes a respite from their sport). In addition, gender differences were captured by collecting responses from coaches across both men's and women's sports. For example, a women's soccer head coach may perceive the impact of the 
LITB policy on his/her student-athletes differently than the responses collected from a men's soccer head coach. Structural factors (e.g., work hours, work scheduling) are mentioned within the policy impact (student-athletes are missing fewer classes since LITB was implemented), contest reductions (LITB allows for more practice time), winter break (winter break disrupts our team activities), and financial savings (LITB creates financial saving by playing fewer games) dimensions. Nite (2012) highlighted the financial constraints faced by NCAA Division II athletic administrators, potentially leading them to seek the financial savings available through the LITB policy. Lastly, sociocultural factors (e.g., cultural norms or pressures) were represented within policy impact (LITB allows our coaches to spend more time with our student-athletes off the playing field) and contest reductions (I wish our team had the option of playing more games).

Once the instrument was developed, the authors vetted it with a panel of experts to assess face and content validity (Creswell, 2012). This panel included an NCAA national office staff member, two Division II athletic administrators, one Division II head coach, and two scholars with expertise in student-athlete research. The panel members provided feedback on the items and their application to the current LITB initiative, their perception of future NCAA/athletic policies on athletic/academic balance, and the target audience (head coaches) for the instrument. The panel found each item relevant to the topic and feasible for addressing future policies addressing athletic/academic balance. The panel did recommend limiting the target audience to head coaches, as they had specific concerns that assistant coaches would lack sufficient familiarity with the LITB policy.

Due to the specific policies within the LITB initiative, certain items applied only to coaches of Fall sports. For example, LITB changed the start date (e.g., the first date student-athletes could report to campus), which affects Fall sports differently than Winter and Spring sports. Fall sports cannot schedule any team-related activities before their reported start date. This is unlike Winter and Spring sports, which can schedule team-related activities once their institution's Fall semester starts. With this study focusing on the comprehensive responses of all NCAA Division II head coaches, the authors removed all items related to the specific impact of LITB policy on Fall sports due to concerns of invalid responses from Winter and Spring sport coaches.

All items used a five-point Likert scale varying from strongly disagree (1) to strongly agree (5). This scale was used for three reasons: (a) the high probability that participants would have familiarity with the format, (b) the participants would have a response option if they did not have an established opinion on the item's topic (undecided), and (c) the data collected would apply to each statistical test for this study. Five items were reverse coded during analysis: three items discussing the LITB-mandated midyear break period and two items asking about the effect of the reduction of total number of contests.

Two of the four identified dimensions reflected prominent themes within the LITB policy (contest reductions and midyear break), with another noting an indirect change created by the initiative's implementation (financial savings). The last dimension assessed the participants' perceptions of the overall effect of LITB on student-athletes (policy). The instrument also included demographic items: the participant's age, gender, ethnicity, sport coached, sport season, number of years employed in college athletics, and current position. 


\section{Procedure and Participants}

After receiving approval from the university institutional review board, the researchers used Qualtrics to create the instrument. The researchers compiled contact information (i.e., e-mail addresses) for every Division II head coach via the staff directory on the athletic department websites for each NCAA Division II institution. To ensure readability, avoid redundant items, and implement correct logic coding within Qualtrics, the researchers conducted a pilot study with 150 Division II coaches. These 150 participants were randomly chosen from the original pool of potential subjects for the study. The pilot study participants were provided the basic details of the study and a link to the survey. One week after the initial e-mail, a reminder e-mail was sent. The findings from the pilot study informed the authors to remove any coaches who oversaw an individual Division I sport at a Division II institution, which would not be associated with the LITB policy. The pilot study participants did not voice any concerns about readability or lack of involvement with LITB. In fact, their responses indicated they were very eager to discuss their opinions on the policy. These responses provided the necessary support to distribute the instrument to the remaining Division II coaches.

Each participant received an e-mail detailing the purpose of the study, contact information for the researchers, approximate time to complete the survey, and a link to the questionnaire. Two weeks after the participants received the initial e-mail, a reminder e-mail was sent to all participants who had yet to complete the survey. Two weeks following the reminder e-mail, the researchers closed the Qualtrics survey. The survey population was all NCAA Division II head coaches within a sport impacted by the LITB initiative $(n=2,796)$. Coaches were chosen as the preferred population because of their intrinsic and extrinsic motivation to facilitate athletic/academic balance for their student-athletes. The sampling frame included the entire population of Division II coaches, specifically any head coach within a LITB-impacted sport listed under each institution's staff directory. Utilizing this technique maximized the generalizability of the results to the population (Dillman, Smyth, \& Christian, 2008). A total of 711 participants completed the survey, for a response rate of $25.4 \%$. Because of the strong response rate for an online survey, the researchers examined the differences between early and late responders. Using a series of one-way ANOVAs, an examination of early versus late responders revealed no statistically significant differences between the two groups. The responses were used for both analyses - the EFA and the CFA.

To conduct the two separate analyses using a single data collection, the researchers performed a split-sample cross validation by separating participants into two groups. Split-sample cross validation has been used in statistical analysis when a researcher collects enough responses to adequately process multiple statistical procedures (e.g., exploratory factor analysis; Reis \& Judd, 2014). The first sample consisted of 242 NCAA Division II coaches (Males $=195$, Females $=47$ ). The group had an average age of 45.2 years $(S D=10.9)$. Participants had an average of $17.4(S D=8.9)$ years of experience in intercollege athletics and an average of $10.1(S D=8.1)$ years in their current position. The second sample consisted of 469 NCAA Division II coaches (Males $=342$, Females $=127$ ). The average age of the group was 43.2 years $(S D=10.8)$, and participants possessed an average of 16.6 $(S D=8.9)$ years of experience in intercollege athletics, with an average of $9.6(S D$ $=8.1$ ) years in their current position. 


\section{Data Analysis}

This research project was completed in two parts. For the first part, the authors concentrated on testing the instrument and purifying the items. This was achieved by conducting an EFA using a principal component method with a varimax rotation. Performing an EFA provides a better understanding of the underlying structure and a purification of the instrument's items (DeVellis, 2012). The EFA was performed using IBM Statistical Package for the Social Sciences (SPSS) version 21.0. The Kaiser-Meyer-Otkin (KMO) and Bartlett's test of sphericity were performed to ensure the feasibility of performing the EFA. To confirm this feasibility, Hutcheson and Sofroniou (1999) recommended both measurements be statistically significant and the KMO measure be .90 or higher to ensure the items are distinct and reliable. The researchers in this study also interpreted the eigenvalues, scree plot, and parallel analysis to determine the number of extracted factors. Lastly, to further reinforce the reliability of the factors, the researchers examined Cronbach's alpha to assess the internal consistency reliability of the items.

The second part focused on the CFA and followed a series of steps. The first step was reporting the descriptive statistics for the items, including their means, standard deviations, skewness, and kurtosis. This information helped assess the normality of the data. The second step was to report the bivariate correlations and identify the amount of variance shared between measures. The third step was to conduct the CFA, utilizing the structure from the EFA performed earlier for further testing of the scale. The CFA was performed using Mplus version 6.12.

The researchers interpreted the fit statistics to appraise the quality and size of the factor loadings for the CFA (Kline, 2004). To ensure the data fit the hypothesized structure from the previously performed EFA, model fit was examined. The authors followed Hu and Bentler's (1999) recommendations of model fit. The four measures were: (a) a nonsignificant chi-square, (b) a 0.95 or above comparative fit index (CIF), (c) a 0.08 or below root-mean squared error of approximation (RMSEA), and (d) a .05 or below standardized root mean of the residual (SRMR). Lastly, factor loadings of .50 or greater were retained to ensure a minimum standardized large factor loadings (Kline, 2004).

\section{Results}

\section{Exploratory Factor Analysis}

The results from the exploratory factor analysis are provided in Table 1. The KMO was .925 and Bartlett's test of sphericity was statistically significant $(p<.001)$, meaning the correlations among the variables were distinct and reliable (Hutcheson $\&$ Sonfroniou, 1999). The total variance explained was $67.14 \%$ while retaining four factors with eigenvalues greater than 1.0. The factor explaining the largest portion of the explained variance, policy impact, was $25.01 \%$. The scree plot and parallel analysis also recommended four factors. After completing the EFA, 22 items were retained to measure four factors of the AABS: (a) Policy Impact ( 10 items: Items, 17, 18, 20, 21, 23, 25, 27, 28, 29); (b) Contest Reductions (5 items: Items 9, 10, 11 , 12, 13); (c) Mid-Year Break (4 Items: Items 5, 6, 7, 8), and (d) Financial Savings (3 Items: Items 14, 15, 16). 


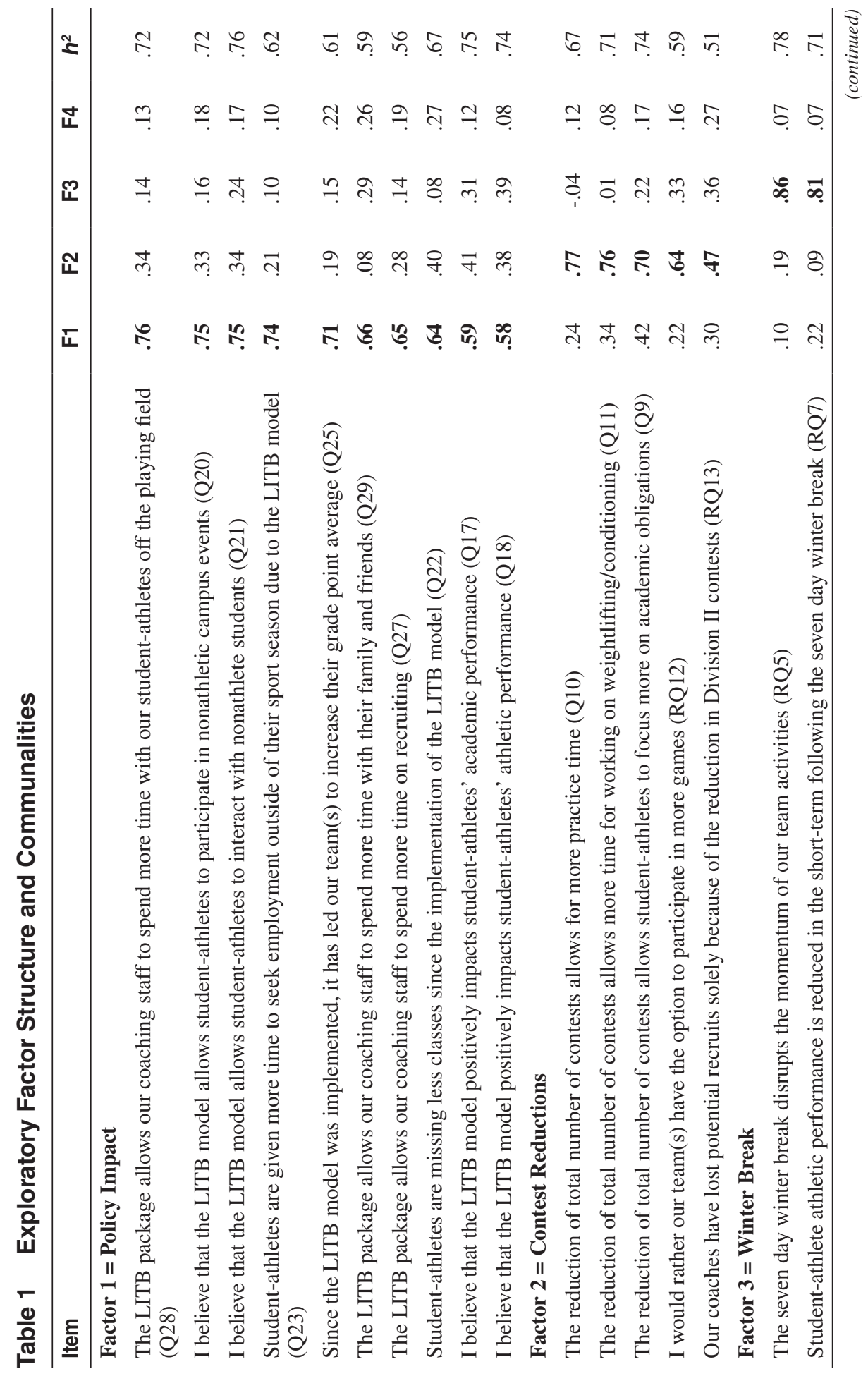




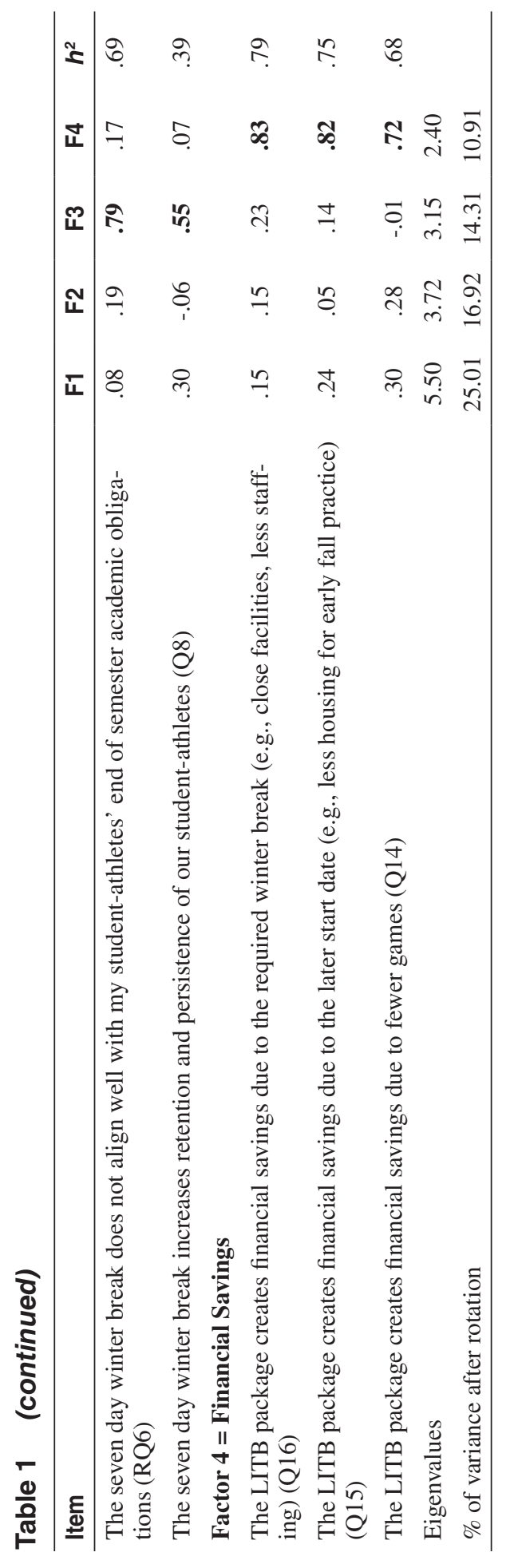


Stevens (2009) recommended only retaining items with .40 or higher to ensure they account for $15 \%$ or more of the variance within the factor. All factor loadings were above a .40 threshold, with only Item 13 ("Our coaches have lost potential recruits solely because of the reduction in Division II contests") below .50. Item 13 may have been close to the threshold because the item discussed the future effect (recruiting) of contest reductions compared with the other items focusing on the current effect.

The reliability and internal consistency were also examined to further reinforce the reliability of the factor structure. The authors examined Cronbach's alpha scores, which Nunnally and Bernstein (1994) recommended either equal or exceed .70. All four factors registered a Cronbach's alpha score above .70, ranging from .94 (Factor 1) to .81 (Factors 3 and 4), further reinforcing the reliability of the structure. Following the EFA results, the second part tested the findings by completing a CFA.

\section{Step 1: Descriptive Statistics}

Reported statistics, in Table 2, include means and standard deviations. Each measure reported an acceptable skew or kurtosis, meaning the data were normally distributed. Item 12, "I would rather our team(s) have the option to participate in more games" had the lowest score of all items $(M=1.88)$. This may be due to the fact that coaches preferred their teams compete in more games than currently allowed under LITB.

\section{Step 2: Bivariate Correlations}

Table 3 provides the bivariate correlations for each item. All reported associations are in the expected direction. When examining the predicted relationships between items, each reported association would qualify as a moderate correlation or higher (Cohen, 1988).

\section{Step 3: Confirmatory Factor Analysis}

Finally, the researchers conducted the CFA with results provided in Table 4. After an initial review of the results, the authors removed one factor, financial savings, to improve the model fit. Financial savings may not represent an ideal factor for these study participants, college coaches, as they may not be informed on the impact of LITB on athletic department budgets. The first part of this analysis included reviewing the goodness of fit. The chi-square for the model was statistically significant. While this is traditionally a concern, Kline (2004) claimed samples of 200 or greater are likely to report a significant chi-square. Because this sample size was greater than 200, alternative fit statistics were a more accurate review of goodness of fit. The CFI was 0.96, RMSEA was 0.05 , and SRMR $=0.06$, indicating the predicted model fit the data.

Following recommendation of fit statistics, analysis of the magnitude of the factor loadings was performed. Seventeen of the 19 items reported large factor loadings (Kline, 2004). Two items, "Our coaches have lost potential recruits to other NCAA divisions or the NAIA solely because of the reduction in Division II contests" (Item 13) and "The seven day winter break increases retention and persistence of our student-athletes" (Item 8) reported factor loadings within Kline's standard of small or moderate impact. This lack of large factor loadings for these two items 


\section{Table 2 Study 1: Responses to Survey Questions on Life in the Balance Initiative from College Coaches at NCAA Division II Institutions}

\begin{tabular}{|c|c|c|}
\hline Question & M & $S D$ \\
\hline $\begin{array}{l}\text { The seven day winter break disrupts the momentum of our team activities } \\
\text { (RQ5) }\end{array}$ & 3.10 & 1.00 \\
\hline $\begin{array}{l}\text { The seven day winter break does not align well with my student-athletes' end } \\
\text { of semester academic obligations (RQ6) }\end{array}$ & 3.23 & 0.94 \\
\hline $\begin{array}{l}\text { Student-athlete athletic performance is reduced in the short-term following the } \\
\text { seven day winter break (RQ7) }\end{array}$ & 2.91 & 0.99 \\
\hline $\begin{array}{l}\text { The seven day winter break increases retention and persistence of our student- } \\
\text { athletes (Q8) }\end{array}$ & 2.73 & 0.82 \\
\hline $\begin{array}{l}\text { The reduction of total number of contests allows student-athletes to focus } \\
\text { more on academic obligations (Q9) }\end{array}$ & 2.37 & 1.13 \\
\hline The reduction of total number of contests allows for more practice time (Q10) & 2.70 & 1.13 \\
\hline $\begin{array}{l}\text { The reduction of total number of contests allows more time for working on } \\
\text { weightlifting/conditioning (Q11) }\end{array}$ & 2.48 & 1.04 \\
\hline $\begin{array}{l}\text { I would rather our team(s) have the option to participate in more games } \\
\text { (RQ12) }\end{array}$ & 1.88 & 1.00 \\
\hline $\begin{array}{l}\text { Our coaches have lost potential recruits to other NCAA divisions or the NAIA } \\
\text { solely because of the reduction in Division II contests (RQ13) }\end{array}$ & 3.05 & 1.16 \\
\hline $\begin{array}{l}\text { The "Life in the Balance" package creates financial savings due to fewer } \\
\text { games (Q14) }\end{array}$ & 3.01 & 1.03 \\
\hline $\begin{array}{l}\text { The "Life in the Balance" package creates financial savings due to the later } \\
\text { start date (e.g., less housing for early fall practice) (Q15) }\end{array}$ & 3.04 & 1.12 \\
\hline $\begin{array}{l}\text { The "Life in the Balance" package creates financial savings due to the } \\
\text { required winter break (e.g., close facilities, less staffing) (Q16) }\end{array}$ & 2.98 & 0.98 \\
\hline $\begin{array}{l}\text { I believe that the Life in the Balance model positively impacts student-ath- } \\
\text { letes' academic performance (Q17) }\end{array}$ & 2.53 & 0.99 \\
\hline $\begin{array}{l}\text { I believe that the Life in the Balance model positively impacts student-ath- } \\
\text { letes' athletic performance (Q18) }\end{array}$ & 2.21 & 0.93 \\
\hline $\begin{array}{l}\text { I believe that the Life in the Balance model allows student-athletes to partici- } \\
\text { pate in nonathletic campus events (Q20) }\end{array}$ & 2.52 & 0.97 \\
\hline $\begin{array}{l}\text { I believe that the Life in the Balance model allows student-athletes to interact } \\
\text { with nonathlete students (Q21) }\end{array}$ & 2.47 & 0.93 \\
\hline $\begin{array}{l}\text { Student-athletes are missing less classes since the implementation of the Life } \\
\text { in the Balance model (Q22) }\end{array}$ & 2.45 & 0.99 \\
\hline $\begin{array}{l}\text { Student-athletes are given more time to seek employment outside of their } \\
\text { sport season due to the Life in the Balance model (Q23) }\end{array}$ & 2.34 & 0.97 \\
\hline $\begin{array}{l}\text { Since the Life in the Balance model was implemented, it has led our team(s) } \\
\text { to increase their grade point average (Q25) }\end{array}$ & 2.33 & 0.82 \\
\hline $\begin{array}{l}\text { The Life in the Balance package allows our coaching staff to spend more time } \\
\text { on recruiting (Q27) }\end{array}$ & 2.33 & 0.90 \\
\hline $\begin{array}{l}\text { The Life in the Balance package allows our coaching staff to spend more time } \\
\text { with our student-athletes outside of the playing field (Q28) }\end{array}$ & 2.17 & 0.84 \\
\hline $\begin{array}{l}\text { The Life in the Balance package allows our coaching staff to spend more time } \\
\text { with their family and friends (Q29) }\end{array}$ & 2.75 & 1.10 \\
\hline
\end{tabular}




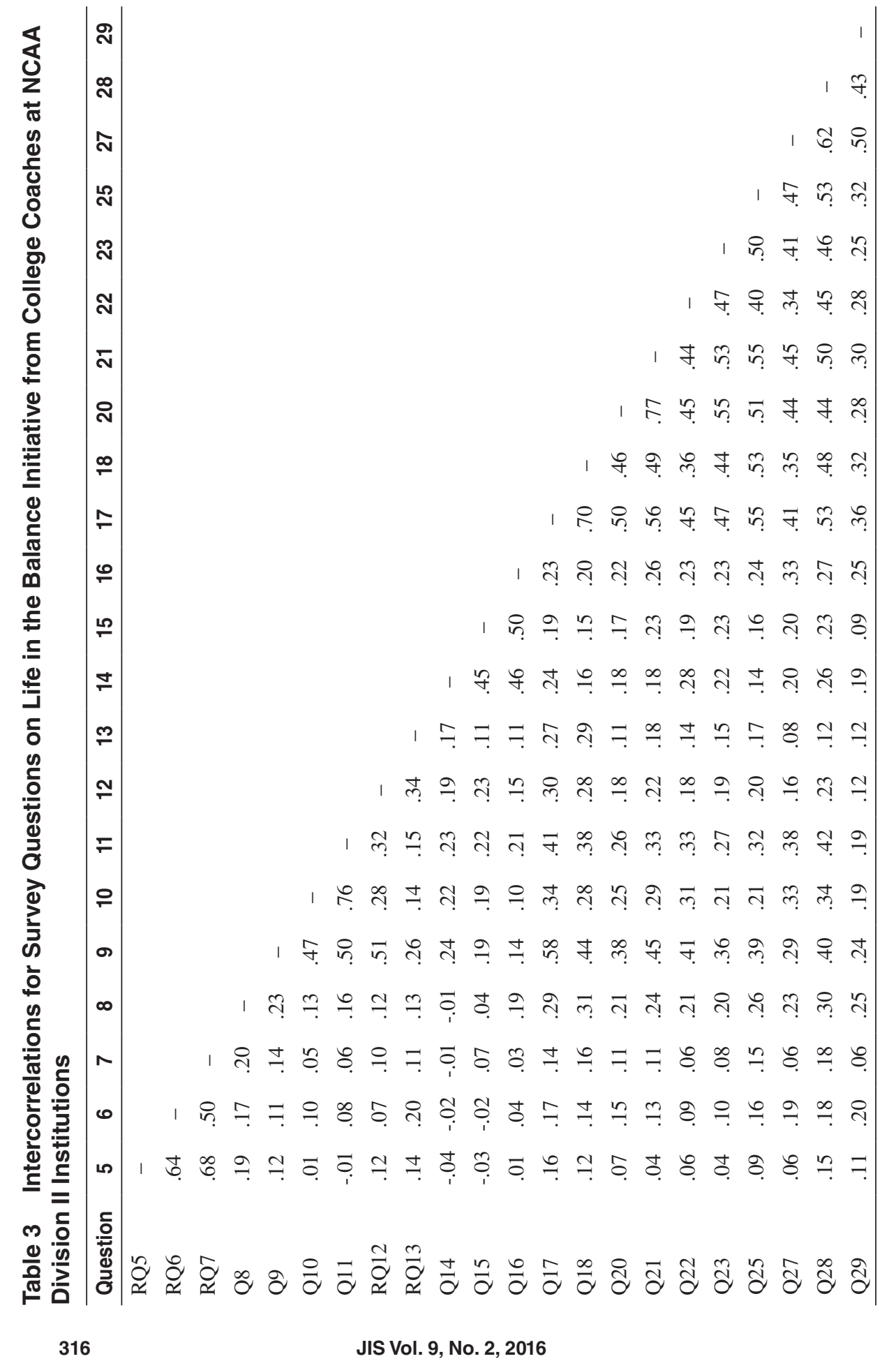


Table 4 Standardized Solutions and Goodness-of-Fit Indicators for the Athletic Academic Balance Scale ( $N=469)$

\begin{tabular}{|c|c|c|c|}
\hline Measures & Factor 1 & Factor 2 & Factor 3 \\
\hline $\begin{array}{l}\text { I believe that the Life in the Balance model positively } \\
\text { impacts student-athletes' academic performance (Q17) }\end{array}$ & $.83 *$ & & \\
\hline $\begin{array}{l}\text { I believe that the Life in the Balance model allows student- } \\
\text { athletes to interact with nonathlete students (Q21) }\end{array}$ & $.83 *$ & & \\
\hline $\begin{array}{l}\text { Since the Life in the Balance model was implemented, it } \\
\text { has led our team(s) to increase their grade point average } \\
\text { (Q25) }\end{array}$ & $.83 *$ & & \\
\hline $\begin{array}{l}\text { The Life in the Balance package allows our coaching staff } \\
\text { to spend more time with our student-athletes outside of the } \\
\text { playing field (Q28) }\end{array}$ & $.81 *$ & & \\
\hline $\begin{array}{l}\text { I believe that the Life in the Balance model allows student- } \\
\text { athletes to participate in nonathletic campus events (Q20) }\end{array}$ & $.80 *$ & & \\
\hline $\begin{array}{l}\text { Student-athletes are given more time to seek employment } \\
\text { outside of their sport season due to the Life in the Balance } \\
\text { model (Q23) }\end{array}$ & $.78 *$ & & \\
\hline $\begin{array}{l}\text { I believe that the Life in the Balance model positively } \\
\text { impacts student-athletes' athletic performance (Q18) }\end{array}$ & $.77 *$ & & \\
\hline $\begin{array}{l}\text { Student-athletes are missing less classes since the imple- } \\
\text { mentation of the Life in the Balance model (Q22) }\end{array}$ & $.75^{*}$ & & \\
\hline $\begin{array}{l}\text { The Life in the Balance package allows our coaching staff } \\
\text { to spend more time with their family and friends (Q29) }\end{array}$ & $.65^{*}$ & & \\
\hline $\begin{array}{l}\text { The reduction of total number of contests allows student- } \\
\text { athletes to focus more on academic obligations (Q9) }\end{array}$ & & $.88 *$ & \\
\hline $\begin{array}{l}\text { The reduction of total number of contests allows more time } \\
\text { for working on weightlifting/conditioning (Q11) }\end{array}$ & & $.57 *$ & \\
\hline $\begin{array}{l}\text { I would rather our team(s) have the option to participate in } \\
\text { more games (RQ12) }\end{array}$ & & $.57 *$ & \\
\hline $\begin{array}{l}\text { The reduction of total number of contests allows for more } \\
\text { practice time (Q10) }\end{array}$ & & $.54 *$ & \\
\hline $\begin{array}{l}\text { Our coaches have lost potential recruits to other NCAA } \\
\text { divisions or the NAIA solely because of the reduction in } \\
\text { Division II contests (RQ13) }\end{array}$ & & $.33 *$ & \\
\hline $\begin{array}{l}\text { The seven day winter break disrupts the momentum of our } \\
\text { team activities (RQ5) }\end{array}$ & & & $.91 *$ \\
\hline $\begin{array}{l}\text { Student-athlete athletic performance is reduced in the short- } \\
\text { term following the seven day winter break (RQ7) }\end{array}$ & & & $.72 *$ \\
\hline $\begin{array}{l}\text { The seven day winter break does not align well with my } \\
\text { student-athletes' end of semester academic obligations } \\
\text { (RQ6) }\end{array}$ & & & $.71 *$ \\
\hline $\begin{array}{l}\text { The seven day winter break increases retention and persis- } \\
\text { tence of our student-athletes (Q8) }\end{array}$ & & & $.24 *$ \\
\hline \multicolumn{4}{|l|}{ Chi-Square $=321.35^{*}$} \\
\hline \multicolumn{4}{|l|}{$\mathrm{CFI}=0.96$} \\
\hline \multicolumn{4}{|l|}{ RMSEA $=0.05$} \\
\hline $\mathrm{SRMR}=0.06$ & & & \\
\hline
\end{tabular}

Note. $\mathrm{CFI}=$ comparative fit index; $\mathrm{RMSEA}=$ root mean square error of approximation; $\mathrm{SRMR}=$ standardized root mean of the residual. $* \mathrm{p}<.05$ 
was consistent with their previously reported weak correlation coefficients. The authors decided to retain both items because their inclusion within the instrument was theoretically based on existing literature. Model modifications were performed on three correlated item pairings: Item 11 with item 10, item 21 with item 20, and item 18 with item 17. The authors concluded the correlation was due to common measurement bias, likely from utilizing the same measurement scale. Because it was assumed to be common measurement bias, the authors allowed the items to correlate. At the conclusion of the CFA, the authors identified three factors, Policy Impact, Contest Reductions, and Mid-Year Break, within the AABS.

A second CFA was performed to further endorse a correlation between the three factors mentioned in the first CFA and a latent variable of Athletic/Academic Balance. The results of the second CFA are presented in Table 5. With no changes in the items, the alternative fit statistics were consistent with the first CFA. One of the factor loadings, Mid-Year Break, did not possess a large factor loading. Similar to the first CFA, the authors retained Mid-Year Break because of its strong foundation within the role theory as it would apply to student-athletes. The authors concluded a confirmation of a latent variable, Athletic/Academic Balance, which correlated with the three previously confirmed factors.

\section{Discussion}

The purpose of this study was to develop a reliable and valid measurement scale assessing coaches' perceptions of balancing athletics and academics for studentathletes. The EFA with the first group of participants predicted the scale would possess four factors. Testing the model using CFA reduced the scale to three factors: (a) policy impact, (b) contest reductions, and (c) midyear break. The proper model fit and large factor loadings supported the data's convergent and discriminant validity.

The conversation of helping student-athletes reduce their time commitment to athletics has begun to include high-level administrators within athletics (Wolverton, 2014) and has been an ongoing discussion in academia for some time (Adler

\section{Table 5 Standardized Solutions and Goodness-of-Fit Indicators for Confirmatory Factor Analysis \#2 ( $=469)$}

\begin{tabular}{lc}
\hline Measures & Factor $\mathbf{1}$ \\
\hline Contest Reductions & $\mathbf{. 0 0}$ \\
Policy Impact & $\mathbf{. 5 4}$ \\
Mid-Year Break & $\mathbf{. 2 3}$ \\
& \\
Chi-Square $=321.35^{*}$ & \\
CFI $=0.96$ & \\
RMSEA $=0.05$ & \\
SRMR $=0.06$ & \\
\hline
\end{tabular}

Note . $\mathrm{CFI}=$ comparative fit index; RMSEA $=$ root mean square error of approximation; $\mathrm{SRMR}=$ standardized root mean of the residual. $* p<.05$ 
\& Adler, 1991; Benford, 2007; Huml, Hancock, et al., 2014; Lally \& Kerr, 2005; Miller \& Kerr, 2003). Big Ten Commissioner Jim Delaney stated almost all NCAA student-athletes spend more than the NCAA maximum-allowed 20 hours a week on athletics. Nathan Hatch, NCAA Division I Board of Directors chair and Wake Forest University President, called for a renewed commitment from colleges and universities to educate student-athletes (Wolverton, 2014). This discussion has expanded to include the possibility of implementing an initiative similar to LITB in Division I athletics (New, 2015), showing the potential of a model regulating the athletic/academic balance of student-athletes across all levels of the NCAA. As these policies are implemented, researchers can investigate effectiveness in achieving intended goals. Identifying the specific facets of a policy, such as the reduction of contests, can help practitioners continuously fine-tune the policy for optimal results.

\section{Theoretical Implications}

While application of role theory within sport has been limited, a recent increase in application of role theory has been applied to various NCAA stakeholders (Bruening \& Dixon, 2007, 2008; Dixon \& Bruening, 2005, 2007; Gibson \& Pennington-Gray, 2005). With role theory examining predictable and socially expected patterns, a theoretical extension into the balance between athletics and academics seems logical and needed. This study expands the findings from those studies into the population of student-athletes through the perceptions of head coaches. While coaches and athletic trainers are employees, there is an ongoing discussion of whether student-athletes are also university employees, lending some support of a connection between their roles within the athletic department. Regardless, the significant time commitment and challenges of balancing athletic obligations and academic opportunities for student-athletes have empirical and theoretical support. The intercollegiate environment student-athletes face can create intense pressure on them to focus on their athletic responsibilities rather than their academic obligations (Lally \& Kerr, 2005; Miller \& Kerr, 2002).

The AABS scale developed in this study is the first scale utilizing one stakeholder's (head coaches) perceptions of the activities of another (student-athletes) using the role theory as the theoretical lens. Previous attempts at using role theory within a sport setting used self-reflections from female college coaches and athletic trainers on their experience within their profession (Bruening \& Dixon, 2007, 2008; Dixon \& Bruening, 2005, 2007; Mazerolle \& Eason, 2013). Expanding this theoretical application to include the coach's perceptions of student-athlete could further develop the examination between other closely related stakeholders within sport. For example, Dixon and Bruening $(2005,2007)$ reported structural challenges discussed by female college coaches within their profession, but it would also be informative to gather information from student-athletes and athletic administrators on what they perceive to be the structural challenges faced by coaches. This type of application can potentially identify challenges/factors being perceived by one group, but not by another.

As mentioned previously, this study's purpose was not to replicate Bruening and Dixon's (2008) multilevel approach, but does highlight potential avenues of applying such a framework to the student-athlete experience. For the individual approach, student-athletes' characteristics and background have been shown to 
influence their decisions on how to use their free time. A recent study examined the use of time by students on a weekly basis (Doerksen et al., 2014), but the differences between the current (Division II) and future (Division I and III) legislation and how it will impact the daily schedule of student-athletes will warrant a further examination. Other studies have also looked into differences based on gender, race, urban/rural upbringing, education level of parents, and socioeconomic status (Bimper, 2015; Epsenshade et al., 2004; Miller \& Kerr, 2003). The NCAA could further examine these individual characteristics and alter LITB to take them into consideration. An example would be assessing student-athlete's level of athletic identity and adjusting the initiative accordingly. One unintended benefit of LITB providing more time for student-athletes away from their sport means coaches can spend more time away from their job as well. Coaches spend an incredible amount of their time focused on their job, even to the detriment of their family stress levels (Bruening \& Dixon, 2007; 2008).

For the structural approach, universities may see increased involvement of student-athletes within intramurals, student organizations, student events (e.g., concerts), and educational resources (e.g., writing centers). Greater involvement by student-athletes within nonathletic university functions could be a positive indicator of their future academic success and potential graduation (Huml, Svensson, \& Hancock, 2014; Kamusoko \& Pemberton, 2011; Miller \& Kerr, 2003). It could also mean athletic department employees are working more closely with other university structures in an effort to find additional educational activities and resources for their student-athletes. In addition, providing greater training to university personnel working with student-athletes, such as managing time constraints and athletic identity, would improve student-athlete academic development. This also applies for coaches, who need to become more involved in helping their student-athletes get connected to academic resources (Comeaux, 2013). With the student-athletes spending additional time away from their sport, coaches can highlight these university resources to improve their academic success and ensure they are informed on their career options.

Lastly, new developments within the sociocultural approach could mean less pressure from athletics personnel on student-athletes to focus on athletic activities over academic activities. Athletic administrators, knowing their student-athletes have a greater amount of free time, may place a greater priority on their academic success. More time away from their sport may ease the pressure on student-athletes to avoid certain majors because of conflicts with their athletic schedule (Fountain \& Finley, 2011). More importantly, if the LITB policy proves successful at Division II, it would provide further support of its implementation at Division I (Wolverton, 2014). A policy governing the time student-athletes spend on athletics per week has strong empirical support, as both student-athletes and coaches have shown a strong desire to spend as much time as possible participating in athletic-related activities (Benford, 2007; Miller \& Kerr, 2003; Wolverton, 2014).

With previous scholars examining the academic experience of student-athletes (Miller \& Kerr, 2002; Warner \& Dixon, 2015) and the balance of academics and athletics for student-athletes (Wolverton, 2014), this study's scale can capture a multitude of topics. The AABS offers two opportunities for future scholars. First, it provides the first scale for assessing the impact of NCAA or athletic department policies related to the athletic and academic balance for student-athletes. Conference 
commissioners and university athletic directors have admitted the amount of time spent by student-athletes on their athletic activities frequently goes beyond the maximum allowed by the NCAA (Wolverton, 2014). These realities may indicate the future implementation of NCAA policies providing additional protections for student-athletes is inevitable. It is unknown what would be included in these future policies, but it is realistic to expect the policies will have to incorporate at least one or two of the AABS subscales to achieve the policy's intended balance between academics and athletics.

Second, the AABS delivers insight into the implementation of the LITB initiative in NCAA Division II intercollegiate athletics. With scholars clamoring for policies protecting student-athletes' time away from athletics (Benford, 2007; Wolverton, 2014), LITB provides a real-life environment to assess the effects of such initiatives, such as how athletic department personnel perceive policies reducing student-athlete involvement in athletics and increasing their involvement in other activities in higher education. While certain facets of LITB may prove impractical for NCAA Division I intercollegiate athletics as a whole, its premise can be applied across all NCAA divisions. The midyear break represents one example of its potential implementation impracticality in its current form at the Division I level. Because of lucrative television contracts for basketball tournaments during the holiday period, it is unlikely Division I institutions would forfeit guaranteed revenues to provide student-athletes time away from their sport.

The only factor loading reported in the EFA, but not in the CFA, regarded financial savings. The original instrument included financial savings because the opportunity to reduce financial expenditures for the athletic department represented one of the LITB initiative's objectives. In addition, any policy initiating a reduction in athletic commitment from student-athletes would potentially involve a reduction of athletic-related events, therefore leading to a decrease in athletic department expenditures. With Division II college coaches as this study's participants, the authors concluded coaches may not have an in-depth knowledge regarding the financial aspects of the athletic department. If coaches only know about their own team's budget, they may not have the necessary information to know if or how LITB will affect the athletic department's overall expenditures. This lack of knowledge on finances related to athletic department expenditures would also apply to studentathletes, meaning that modification of items related to financial savings may be necessarily for future studies depending on the participants.

\section{Limitations and Future Research}

A major limitation of this study was its sample population, focusing specifically on the perceptions of Division II head coaches. A future study should collect data from student-athletes, as their perspective would provide a more accurate account on their experience balancing academics and athletics. It would be interesting to examine whether student-athletes actually wish to find a balance between athletics and academics, as they may be more strongly motivated to participate in athletics over academics. While this study centered on instrument development, a future study may gather the opinions of coaches on both the impact of LITB and the concept of improved student-athlete balance between athletics and academics. A study in the 
future may want to measure student-athletes' use of time, such as time spent on certain activities (e.g., athletic activities compared with academic-related activities). While this study primarily focused on validating an instrument for assessing the athletic/academic balance, further studies will need to explore the instrument and further reinforce the AABS scale. Lastly, this study's scope was limited to participants connected to Division II institutions. A future study may expand the scale to incorporate constituents from and aspects germane to NCAA Division I and III.

\section{Conclusion}

The lives of NCAA student-athletes have become more complicated over time. Pressure to succeed in the classroom and on the playing field continues to mount. It is important that athletic department personnel, particularly coaches and administrators, do all they can to contribute to their student-athletes' well-being. NCAA Division II administrators took the first step in establishing a policy, Life in the Balance, with hopes of helping student-athletes find a more manageable way to be successful. The lesson learned here, however, is that when mandating policy reform, sport governing bodies need to take into consideration an assortment of stakeholders. According to the Birkbeck Sport Business Centre (2010, p. 6), national sport governing bodies "should seek to implement stakeholder engagement and stakeholder participation strategies appropriate to the position of stakeholders on a power/interest matrix." This is why surveying coaches in this study was essential. Coaches are inextricably linked with their student-athletes and so understanding their perceptions of how to improve the lives of those student-athletes can help NCAA policy makers determine best practices to improve student-athlete welfare. NCAA policy makers must, however, include stakeholders such as coaches in this process.

The development of the AABS provides a vehicle to assess perceptions of pivotal stakeholders in NCAA sport. This study laid the groundwork with coaches, and from here the instrument can be used to gather information on academic-athletic balance from other stakeholders (student-athletes, athletic administrators) as well. Information from all these stakeholders will help create a mosaic that can be pieced together to help improve the well-being of future student-athletes

\section{References}

Adler, P.A., \& Adler, P. (1991). Backboards and blackboards: College athletes and role engulfment. New York, NY: Columbia University Press.

Barnett, R., \& Gareis, K. (2006). Role theory perspectives on work and family. In M. Pitt-Catsouphes, K.K. Kossek, \& S.A. Sweet (Eds.), The work and family handbook: Multi-disciplinary perspectives and approaches (pp. 209-222). Mahwah, NJ: Earlbaum.

Benford, R.D. (2007). The college sports reform movement: Reframing the "edutainment" industry. The Sociological Quarterly, 48, 1-28. doi:10.1111/j.1533-8525.2007.00068.x

Bell, L.F. (2009). Examining academic role-set influence on the student-athlete experience (Special Issue). Journal of Issues in Intercollegiate Athletics, 2, 19-41.

Biddle, J. (1986). Recent development in role theory. Annual Review of Sociology, 12, 67-92. doi:10.1146/annurev.so.12.080186.000435

Bimper, A.Y., Jr. (2015). Lifting the veil: Exploring colorblind racism in Black student athlete experiences. Journal of Sport and Social Issues, 39, 225-243. doi:10.1177/ 0193723513520013 
Birkbeck Sport Business Centre. (2010). Good governance in sport: A survey of UK National Governing Bodies of sport. Retrieved from http://www.sportbusinesscentre.com/wpcontent/uploads/2012/08/NGBGovernanceReport2.pdf

Brewer, B.W., Van Raalte, J.L., \& Linder, D.E. (1993). Athletic identity: Hercules' muscles or Achilles heel? International Journal of Sport Psychology, 24, 237-254.

Bruening, J.E., \& Dixon, M.A. (2007). Work-family conflict in coaching II: Managing role conflict. Journal of Sport Management, 21, 471-496. doi:10.1123/jsm.21.4.471

Bruening, J.E., \& Dixon, M.A. (2008). Situating work-family negotiations within a life course perspective: Insights on the gendered experiences of NCAA Division I head coaching mothers. Sex Roles, 58(1-2), 10-23. doi:10.1007/s11199-007-9350-x

Cantor, N. E., \& Prentice, D. A. (1996). The life of the modern-day student-athlete: Opportunities won and lost. Paper presented at the Princeton Conference on Higher Education, Princeton University, Princeton, NJ.

Cohen, J. (1988). Statistical power analysis for the behavioral sciences (2nd ed.). Hillsdale, NJ: Erlbaum.

Comeaux, E. (2015). Practitioner views of college head coaches: A stakeholder management perspective. Journal for the Study of Sports and Athletes in Education, 9, 102-116.

Creswell, J.W. (2012). Educational research: Planning, conducting, and evaluating quantitative and qualitative research (4th ed.). Boston, MA: Pearson Education.

Comeaux, E. (2013). Rethinking academic reform and encouraging organizational innovation: Implications for stakeholder management in college sports. Innovative Higher Education, 38, 281-293. doi:10.1007/s10755-012-9240-1

Cummins, P., \& O'Boyle, I. (2015). Psychosocial factors involved in transitions from college to postcollege careers for male NCAA Division-I basketball players. Journal of Career Development, 42, 33-47. doi:10.1177/0894845314532713

DeVellis, R.F. (2012). Scale development: Theory and applications (3rd ed.). Thousand Oaks, CA: Sage Publications.

Dillman, D.A., Smyth, J.A., \& Christian, L.M. (2008). Internet, mail, and mixed-mode surveys: The tailored design method. New York, NY: John Wiley \& Sons.

Dixon, M.A., \& Bruening, J.E. (2007). Work-family conflict in coaching I: A top-down perspective. Journal of Sport Management, 21, 377-406. doi:10.1123/jsm.21.3.377

Dixon, M.A., \& Bruening, J.E. (2005). Perspectives of work-family conflict in sport: An integrated approach. Sport Management Review, 8, 227-253. doi:10.1016/S14413523(05)70040-1

Doerksen, S.E., Elavsky, S., Rebar, A.L., \& Conroy, D.E. (2014). Weekly fluctuations in college student leisure activities and well-being. Leisure Sciences, 36, 14-34. doi:10.1080/ 01490400.2014 .860778

Espenshade, T.J., Chung, C.Y., \& Walling, J.L. (2004). Admission preferences for minority students, athletes, and legacies at elite universities. Social Science Quarterly, 85, 1422-1446. doi:10.1111/j.0038-4941.2004.00284.x

Fountain, J.J., \& Finley, P.S. (2011). Academic clustering: A longitudinal analysis of a Division I football program. Journal of Issues in Intercollegiate Athletics, 4, 24-41.

Giacobbi, P.R., Roper, E., Whitney, J., \& Butryn, T. (2002). College coaches' views about the development of successful athletes: A descriptive exploratory investigation. Journal of Sport Behavior, 25, 164-180.

Gibson, H.J., \& Pennington-Gray, L. (2005). Insights from role theory: Understanding golf tourism. European Sport Management Quarterly, 5, 443-468. doi:10.1080/16184740500430330

Gilson, T.A., Paule-Koba, A.L., \& Heller, E.A. (2013). The social-psychological implications of a coaching change at the collegiate level: Perceptions of athletes. Journal of Intercollegiate Sport, 6, 164-178. doi:10.1123/jis.6.2.164

Greenhaus, J.H., Collins, K., \& Shaw, J. (2003). The relation between work-family balance and quality of life. Journal of Vocational Behavior, 63, 510-531. doi:10.1016/S00018791(02)00042-8 
Greenhaus, J.H., \& Powell, G.N. (2003). When work and family collide: Deciding between competing role demands. Organizational Behavior and Human Decision Processes, 90, 291-303. doi:10.1016/S0749-5978(02)00519-8

Hardin, R., \& Pate, J.R. (2013). Playbook vs. textbook: Examining academic transitioning of NCAA Division I-FBS football student-athletes. Journal for the Study of Sports and Athletes in Education, 7, 229-244. doi:10.1179/1935739713Z.00000000014

Hendrickson, B. (2013). DII Management Council ponders coaches' census answers. NCAA. Retrieved from http://www.ncaa.org/about/resources/media-center/news/diimanagement-council-ponders-coaches'-census-answers

Hu, L., \& Bentler, P.M. (1999). Cutoff criteria for fit indexes in covariance structure analysis: Conventional criteria versus new alternatives. Structural Equation Modeling, 6, 1-55. doi:10.1080/10705519909540118

Huml, M.R., Hancock, M.G., \& Bergman, M.J. (2014). Additional support or extravagant cost? Student-athletes' perceptions on athletic academic centers. Journal of Issues in Intercollegiate Athletics, 7, 410-430.

Huml, M.R., Svensson, P.G., \& Hancock, M.G. (2014). Exploring the role of educational institutions in student-athlete community engagement. Journal of Issues in Intercollegiate Athletics, 7, 224-244.

Hutcheson, G.D., \& Sofroniou, N. (1999). The mutivariate social scientist: Introductory statistics using generalized linear models. Thousand Oaks, CA: Sage Publications. doi:10.4135/9780857028075

Johnson, J.E., Pierce, D.A., Tracy, D.R., \& Ridley, M.J. (2015). The influence of football head coaching change in the football championship subdivision: An evaluation of the NCAA Academic Progress Rate. Journal of Sport Behavior, 38, 26-51.

Kamusoko, S.D., \& Pemberton, C.L.A. (2011). Student-athlete wellbeing and higher education persistence. Journal of Issues in Intercollegiate Athletics, 4, 207-235.

Kline, R. (2004). Principes and practices of structural equation modeling. New York, NY: Guildford.

Kulics, J.M., Kornspan, A.S., \& Kretovics, M. (2015). An analysis of the academic behaviors and beliefs of Division I student-athletes: The impact of the increased percentage toward degree requirements. College Student Journal, 49, 1-12.

Lally, P.S., \& Kerr, G.A. (2005). The career planning, athletic identity, and student role identity of intercollegiate student athletes. Research Quarterly for Exercise and Sport, 76, 275-285. PubMed doi:10.1080/02701367.2005.10599299

Lawrence, S.M., Harrison, C.K., \& Stone, J. (2009). A day in the life of a male college athlete: A public perception and qualitative campus investigation. Journal of Sport Management, 23, 591-614. doi:10.1123/jsm.23.5.591

Mazerolle, S.M., \& Eason, C.M. (2013). Work-life balance: A perspective from the athletic trainer employed in the NCAA Division I setting. Journal of Issues in Intercollegiate Athletics, 6, 236-248.

Miller, P.S., \& Kerr, G.A. (2002). The athletic, academic and social experiences of intercollegiate student-athletes. Journal of Sport Behavior, 25, 346-367.

Miller, P. S., \& Kerr, G. A. (2003). The role experimentation of intercollegiate student athletes. The Sport Psychologist, 17, 196-219.

Navarro, K.M. (2015). An examination of the alignment of student-athletes' undergraduate major choices and career field aspirations in life after sports. Journal of College Student Development, 56, 364-379. doi:10.1353/csd.2015.0034

NCAA. (2010a). Division II "Life in the Balance" initiative: An overview of four proposals for the 2010 NCAA Convention. Indianapolis, iN: Author.

NCAA. (2010b). Phase II of the Life in the Balance initiative. Indianapolis, IN: Author.

New, J. (2015, January 14). Autonomy faces first test. Retrieved from https://www.insidehighered.com/news/2015/01/14/power-five-members-flex-new-legislative-musclesncaa-convention 
Nite, C. (2012). Challenges for supporting student-athlete development: Perspectives from an NCAA Division II athletic department. Journal of Issues in Intercollegiate Athletics, 5, 1-14.

Nunnally, J.C., \& Bernstein, I.H. (1994). Psychometric theory (3rd ed.). New York, NY: McGraw Hill.

Paule, A.L., \& Gilson, T.A. (2010). Current collegiate experiences of big-time, non-revenue, NCAA athletes. Journal of Intercollegiate Sport, 3, 333-347. doi:10.1123/jis.3.2.333

Reis, H.T., \& Judd, C.M. (2014). Handbook of research methods in social and personality psychology (2nd ed.). New York, NY: Cambridge University.

Stevens, J. (2009). Applied multivariate statistics for the social sciences (5th ed.). New York, NY: Routledge.

The Coalition On Intercollegiate Athletics. (2005). Academic integrity in intercollegiate athletics: Principles, rules, and best practices. Retrieved from http://blogs.comm.psu.edu/ thecoia/wp-content/uploads/Academic-Integrity-in-Intercollegiate-Athletics-2005.pdf

Warner, S., \& Dixon, M.A. (2015). Competition, gender and the sport experience: An exploration among college athletes. Sport Education and Society, 20, 527-545. doi:1 $0.1080 / 13573322.2013 .774273$

Weight, E. A., Cooper, C. G., \& Popp, N. K. (2015). The coach-educator: NCAA Division I coach perspectives about an integrated university organizational structure. Journal of Sport Management, 29, 510-522.

Wilson, M.J., \& Burke, K.L. (2013). NCAA Division I men's basketball coaching contracts: A comparative analysis of incentives for athletic and academic team performance between 2009 and 2012. Journal of Issues in Intercollegiate Athletics, 6, 81-95.

Wolverton, B. (2014, December 11). Payments for athletes? Check. Players with balanced lives? Not so much. The Chronicle of Higher Education. Retrieved from http://chronicle. com/article/Payments-for-Athletes-Check/150807 